\title{
The Significance of Restrictions on Waste Import in Promoting Green Development in China
}

\author{
Chunlin Li, Jianqing Chen* \\ Law School, Fuzhou University, Fuzhou, China \\ Email address: \\ aaronpower@foxmail.com (Jianqing Chen) \\ ${ }^{*}$ Corresponding author
}

To cite this article:

Chunlin Li, Jianqing Chen. The Significance of Restrictions on Waste Import in Promoting Green Development in China. American Journal of Environmental Protection. Vol. 8, No. 1, 2019, pp. 5-16. doi: 10.11648/j.ajep.20190801.12

Received: December 4, 2018; Accepted: January 2, 2019; Published: January 28, 2019

\begin{abstract}
Since its reform and opening up, China's economy has been developing rapidly, but at the same time, China's resources and environment have been increasingly seriously exhausted and damaged. There have been many world-famous public nuisance incidents in developed countries however, pollution caused by solid waste (i.e., garbage) is no less harmful than these international public nuisances. For China, the problem of solid waste import is especially serious and has become a nightmare for the development of environmental protection. The treatment of foreign waste import is an important fundamental approach for China to realize economic transition and promote the expansion of international trade. This paper studies and analyzes the harms of imported waste, explores the practical problems and difficulties in the treatment of imported foreign waste in China and provides a breakthrough concept of green development to promote the expansion of international trade and economic transition by placing a restriction or even ban on foreign waste import. To protect its ecological environment, China has accelerated the process of institutionalizing foreign waste import and economic transition, improved the legislation and law enforcement mechanisms for the treatment of waste import, and encouraged public participation in economic transition and environmental protection. The concepts of waste import restriction and green development provide an important reference for the world.
\end{abstract}

Keywords: Foreign Waste, Waste Import, Green Development, Economic Transition, Sustainable Development

\section{Introduction}

Foreign waste import mainly refers to the general term of solid waste, such as electronic waste, that is exported by developed countries to developing countries. Driven by interest, waste import has formed an industrial chain, and some places in China have even formed foreign waste villages and foreign waste towns (see Figure 1), which has been seriously affecting the economic growth, the environmental protection and the public health of China. In general, a large proportion of waste enters China in the form of smuggling. Due to the absence of standardized inspection and quarantine procedures and treatment processes, foreign waste has caused serious pollution. Gas, biochemistry, heavy metals and other hazards from foreign waste cause long-term harm to the environment, which not only endangers the health of relevant practitioners in the chain of the foreign waste industry but also causes pollution to soil, water, the environment and ecology across large areas.

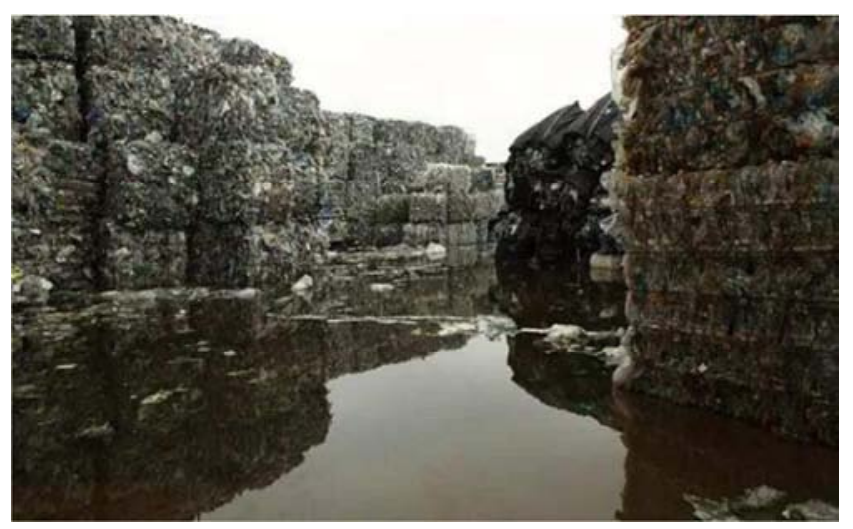




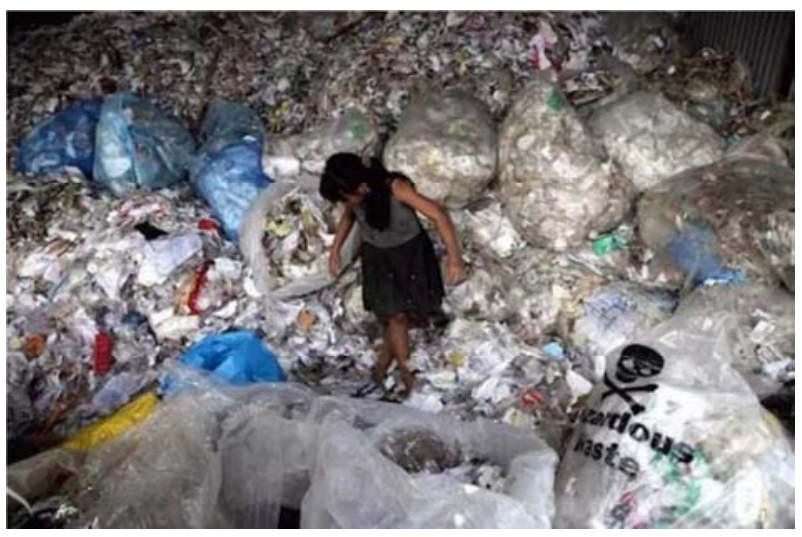

Figure 1. Town of Foreign Waste in China.

Since the reform and opening-up of its economy, China, to some extent, has implemented the strategy of utilizing imported waste to make up for shortage in resources. Since the 1980s, with the rapid development of China's economy, domestic demand for raw materials has increased annually. To alleviate the shortage of domestic raw materials, domestic enterprises began to import solid waste from abroad [1]. With the increase of the entry of foreign waste, environmental pressure facing China has increased rapidly. In the process of importing solid waste for recycling, poisonous and harmful waste has also been entering China in large quantities. China has become a landfill site for some developed countries to dump garbage. Such foreign waste has caused great pressure on China's weak ecological environment.

China once advocated and protected the normal use of waste and recyclable materials as raw materials and allowed for the import of recyclable materials from abroad under strict conditions. However, some foreign enterprises illegally took advantage of the policy by adding unrecyclable waste into the recyclable waste export, and even directly claimed that the unrecyclable waste was recyclable in the export of customs declaration. At the same time, it is an undeniable fact that there are also a few Chinese enterprises that actively offer to collude with foreign enterprises in the importation of foreign waste (Figure 2).

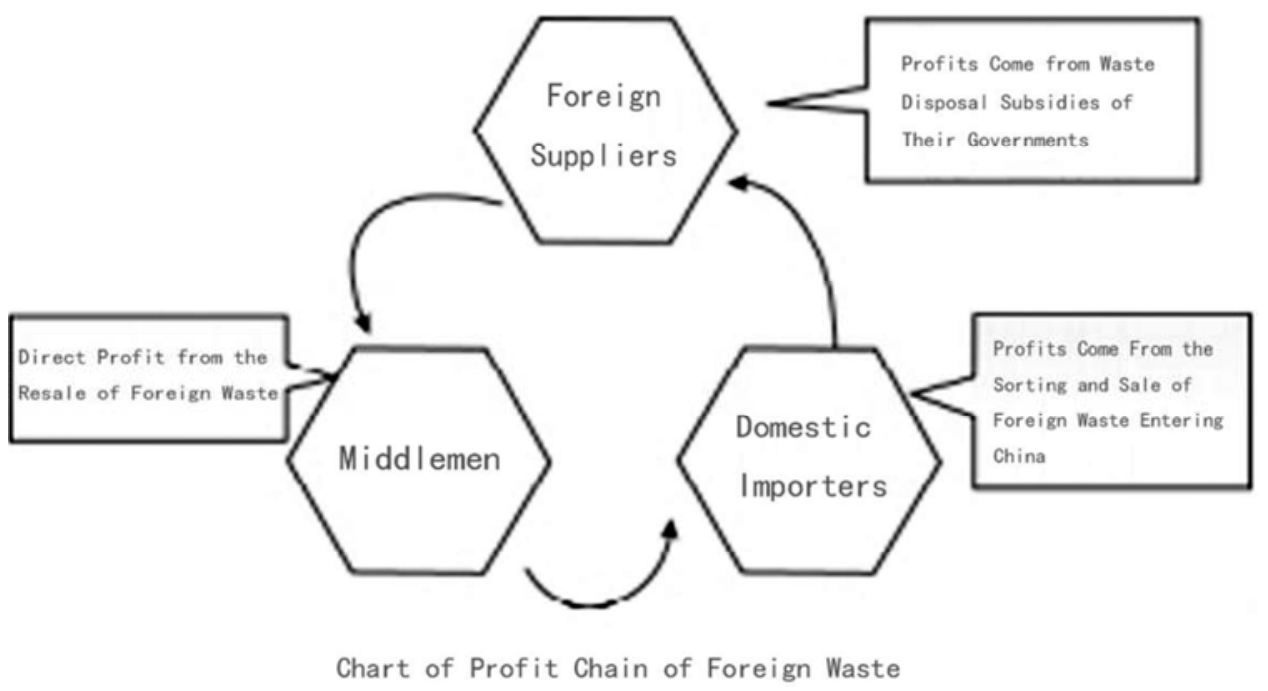

Figure 2. Chart of Profit Chain of Foreign Waste Dealings.

In the past few decades, China has been a country with a high-speed economic growth model that is at the expense of the environment. After all, this pattern of economic growth is unsustainable, and the problems have gradually become apparent. Now, it is the time for an economic transition in China. Only by taking a new path of green development can China's dilemma of sustainable development be solved. Under such a background, the Chinese government began to restrict or even ban the import of foreign waste.

\section{Reasons for Restricting the Import of Waste in China}

\subsection{The Harm to Environmental and Public Health}

There are two kinds of environmental pollution that can often be seen, namely, production pollution and product pollution. The pollution caused by the international waste import belongs to product pollution. The export of waste, especially hazardous waste, can cause serious human health problems and environmental damage in countries that import. As underdeveloped countries do not have the funds, technical capacity, and necessary infrastructures to properly dispose of hazardous waste, then improper disposal can damage local air, water and other natural resources (see Figure 3). In turn, this can cause damage to the health of the local population, including neurological diseases, fertility decline, and other severe effects, such as cancer. The vast majority of developing countries lack the ability for governance of imported waste, and, similar to China, may import waste, which greatly increases the future costs of cleaning up environmental pollution, and also results in long-term damage to public health and the natural environment. 

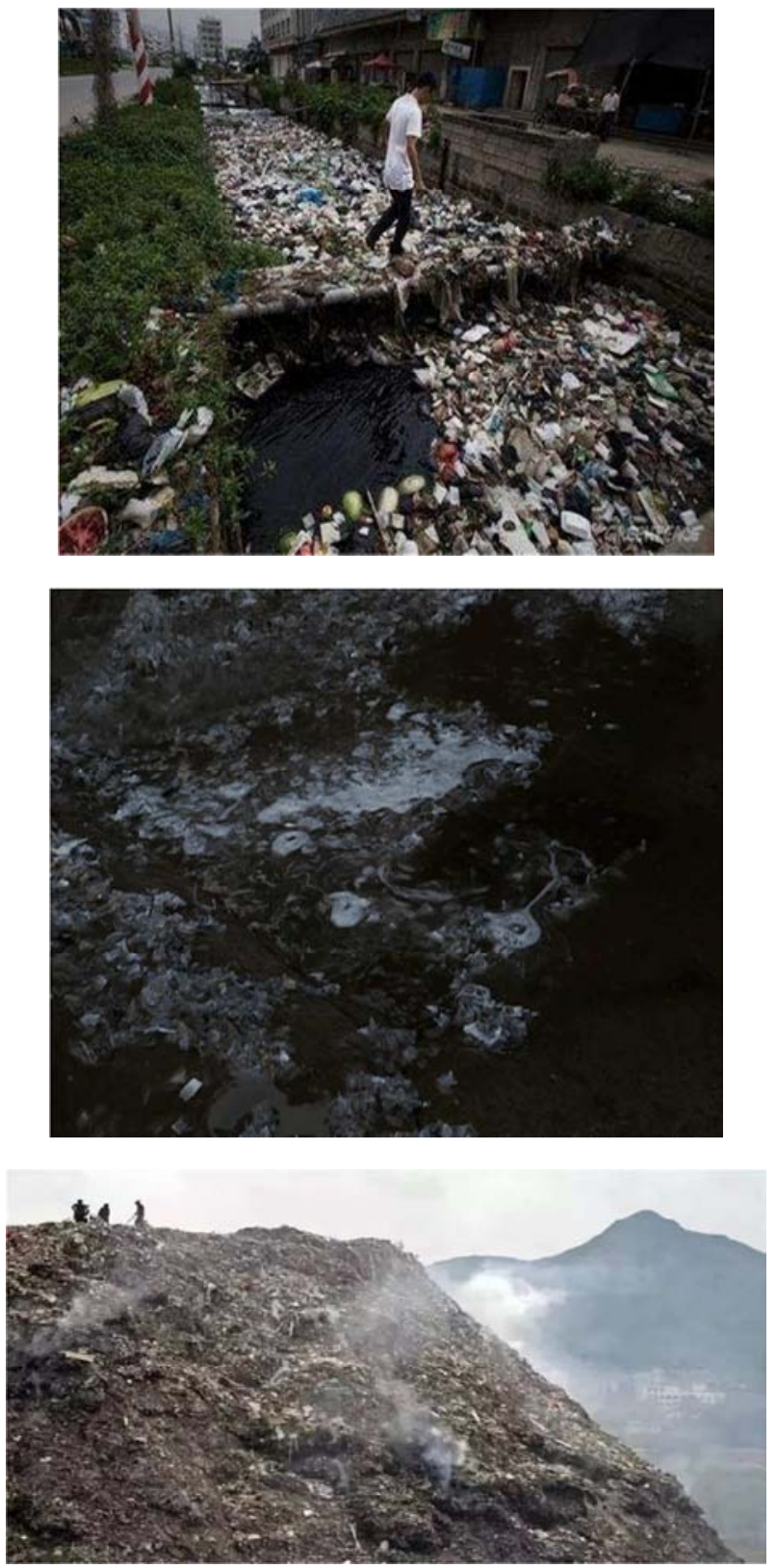

Figure 3. Polluted Water and Air.

\subsection{The Economic and Social Costs Far Outweigh Its Economic Value}

There are several reasons why China should restrict waste import. On the one hand, the damage or harm caused by imported waste to the local environment and public health has become increasingly visible; on the other hand, with the concept of green development, China's economy has reached a new stage, and the value of waste has been greatly reduced. The cost for treating the pollution from foreign waste far exceeds its economic value.

In seeing the statistical data of the National Bureau of Statistics (see Figure 4), we can find that before 2011, the import of waste plastics in China showed an overall trend of obvious growth. Especially in 2011, the import of waste plastics was as high as more than 8.8 million tons. After 2011, there was a downward trend, because the ecological environment was seriously damaged, and China strengthened its environmental protection measures. Faced with the heavy blow of environmental protection, many enterprises chose to withdraw from the waste plastics processing industry or had to suspend the work temporarily. Therefore, from the data of the figure, the enterprises of waste solid treatment investment obviously decreased since 2011, and the investment amount obviously reduced. In the years 2016 and 2017, environmental problems became increasingly apparent with the appearance of haze weather increasing. The environmental treatment cost caused by the pollution of foreign waste has been increasing, so its economic value has been unable to meet the cost of pollution control.

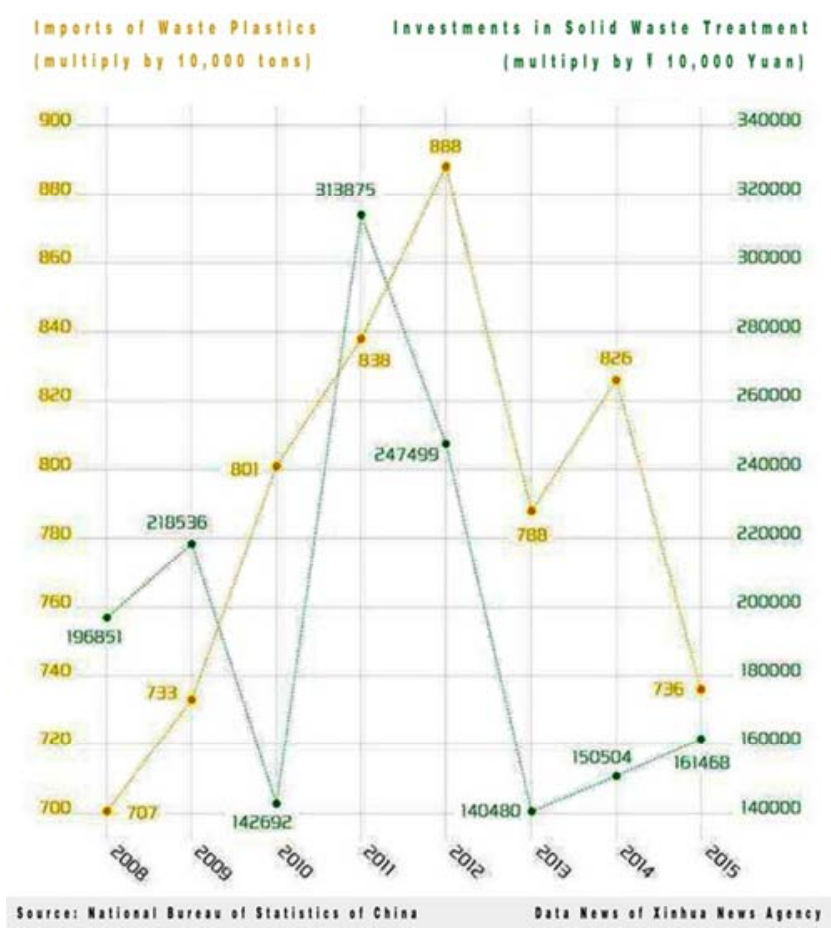

Figure 4. Import Quantity of Waste Plastics and Investments in Solid Waste Treatments in China in Recent Years.

\subsubsection{The Economic Value of Imported Waste}

In the 1980s, to make up for the shortage of raw materials in domestic industrial production, China began to import solid waste which can be used as raw materials. However, moral rationales also appeared, in an inert form [2]; at the same time, in the form of smuggling, waste in the form of used clothing, electronic products and other foreign waste poured into the country. In the past, a portion of solid waste that can be used as feedstock has played a role in filling domestic resource shortages at specific stages of development. Take waste paper as an example; with the rapid development of the economy, China's consumption of paper has grown rapidly. The per capita forest area of China is only $1 / 4$ of the world level, so the moderate import of waste paper fills the gap of pulp demand. In addition, the import of waste plastics can also reduce China's dependence on oil imports to a certain extent. Furthermore, due to the rapid development of China's 
economy, the demand for metal resources is large, and some imported waste, with steel scrap as an example, can supplement the gap in energy. Therefore, China is also a big importer of steel scrap. Data showed that in 2013, 85 million 700 thousand tons of steel scrap were consumed in China, which accounts for approximately $15 \%$ of global steel scrap consumption, and the consumption of steel scrap reached 88 million 300 thousand tons in 2014, which was an increase of $3 \%$ over the same period of last year [3].

\subsubsection{The Cost of Ecological Restoration}

The harm from waste import is first manifested in the destruction of the ecological environment. In some areas, such as Guangxi, Guangdong, and Zhejiang provinces, environmental pollution is especially obvious. Coastal provinces are the preferred destinations for the trans-sea transport of international wastes because of the convenience of sea transportation, while provinces such as Guangxi have borders with other countries in Southeast Asia, which makes it relatively easy to import waste. The rationality of citizen preferences and the discourse that is appropriate to them has what might be called a substantive dimension, concerning the "better and worse" view of life [4]. Therefore, some villages and towns in these provinces have become the worst-hit areas for foreign waste to pollute the local ecological environment. Most waste is dealt with in small workshops, which consume many energy and water resources and pollute farmland, rivers and air. Then, many pathogens cause people to get sick. Unfortunately, controlling pollution requires many manpower and material resources, and the cost of ecological restoration is hundreds of times of its profits.

\subsubsection{The Cost of Public Health}

Some villages and towns in some provinces of China are plagued by imported waste. In Mancheng, which is in Baoding City of Hebei Province, the processing of plastic waste has caused serious air and water pollution. For more than a decade, groundwater in some villages has been undrinkable, and the air is filled with the pungent smell of plastic burning every day. More and more local people are suffering from cancer. The root cause of these changes is the overspread of waste. The tailings of foreign waste, which were sorted out for no more use, were burned, and some villages were fully covered by thick smoke. The waste is too much to dispose of, so it can only be burned. In the evening, the pungent smell from the plastic burning keeps the villagers from sleeping in some villages [5]. The main chemical components of plastics are polytene, saran, polyvinyl chloride and polystyrene. When burning, the plastics produce and release toxic gases such as dioxin, benzene, and carbon monoxide, etc., as well as a large amount of dust particles (see Figure 5). When people inhale, it can cause coughing, memory loss, and even cancer. Impoverished communities often live in substandard environments [6]. To change the situation, the path of green sustainable development must be taken.

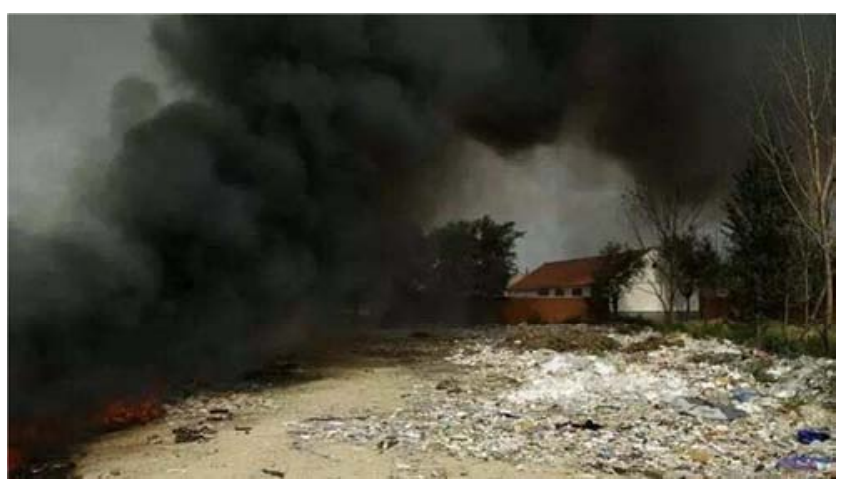

Figure 5. Pungent Smell of Plastic Burning

In addition, the pollution caused by waste materials such as recycled electronic products and clothing in waste imports should not be underestimated. The special chemical components, such as nickel and mercury, in electronic products may leak over time. They are directly harmful to the human body. If discarded, they will also cause long-term pollution to the land. Because of its particularity, clothing makes direct contact with human skin, so the bacteria it may carry are more harmful to the human body than to electronic products. Most of these imported waste garments come from garbage dumps and come into contact with various sources of pollution, but businessmen are less likely to sterilize them because of the high cost, so it poses a greater threat to consumers.

\subsection{The Change of the Economic Development Mode}

\subsubsection{Unsustainability of the Resource-Consuming Economic Development Mode}

China's reform and opening-up economic policy has continued to maintain a fast rate of growth in the past 40 years. However, there are many problems in the pattern of economic growth. The Chinese government is now deeply aware of the problems and has been determined to change the economic growth pattern, which relies excessively on the increase in consumption of material resources, the extensive expansion of scale, high-energy consumption and high-emission industries to fundamentally improve the ecological environment fundamentally. Meanwhile, the comprehensive management of environmental pollution will be strengthened, and an advancement in the renovation of ecological protection will be accelerated. For a long time, the economic growth of China has been accompanied by potential threats. A one-sided emphasis on the promotion of economic indicators has led to the neglect of environmental protection. The annual rise of the GDP index is accompanied by the costs of sacrificing the natural environment. Currently, environmental problems in China have become very prominent and have even become a bottleneck restricting the development of the national economy. Promoting the formation of a green development style and green lifestyle is a profound revolution in China. The green movement determines life and death, as well as the future and, thus, concerns the well-being of future generations [7]. In some places in China, environmental problems have 
threatened the survival of local people, and such phenomena as "cancer villages" and "environmental migrants" have emerged from time to time. How to curb the deterioration of the living environment is not just an economic issue that must be taken seriously by the Chinese governments; it is also a major political issue that is related to the survival and sustainable development of the nation.

\subsubsection{Awareness of Green Sustainable Development}

Along with its reform and opening up, the national economy of China has realized the development in leaps and bounds. However, the fast economic growth rate has not brought about an overall improvement in the standard of living of people in China. In contrast, with the growth of its economy, China's natural environment has been seriously damaged. Currently, environmental problems have restricted the development of its economy. In addition, environmental issues have become the first priority for the survival of its citizens. The faster the economic growth, the worse the living environment, which has become a strange development phenomenon in China. The management of public affairs requires a balanced collaboration and interaction between the government and citizens [8]. Fortunately, the Chinese government and its people have generally recognized the importance of achieving green sustainable economic development. They began to strengthen the publicity and education of environmental protection and set up a correct concept for environmental protection. From the aspect of publicity for environmental protection, multichannel and multiplatform public service advertising have an impact on people, which makes people realize that environmental protection not only brings economic benefits but also brings the benefits of a good quality of life and that stimulates people's motivational force for environmental protection. Through public service advertisements on television, public service advertisements on covers of books, environmental protection exhibitions and environmental protection lectures organized by relevant departments, etc., China has constantly improved publicity and education. Furthermore, people become stimulated by the awareness of the sanitary and environmental benefits of material recovery [9]. Therefore, people can understand that China's economic development has come to a time when green sustainable development must be adopted. Restriction on waste import and fundamentally cutting off the interest in the foreign waste smuggling chain have become necessary.

\section{Materials and Methods}

\subsection{Policy Evolution}

\subsubsection{Encouragement of the Import of Waste to Make up for the Shortage of Resources}

China began to import waste in the 1980 s. China was very poor at the time and needed to develop its economy to improve people's livelihood and promote the prosperity of the country. Economic growth, then, was the first priority. People focused only on the growth of the GDP, without regard for the quality of the economic development. The expansion of the production scale by increasing the input of factors of production to achieve economic growth was commonly seen. As a results of that approach to economic growth, resource consumption was high and economic benefits were low. Therefore, at that time, due to technological backwardness, China often had to export resources in exchange for foreign-currency reserve and its economic growth in international trade. Essentially, garbage represents a physical reality rather than folklore or mythology. For each individual, there are two realities: the mental reality, which encompasses beliefs, attitudes and ideas; and the material reality, which is the picture that is developed from the physical record [10]. In that case, China, in some sense, encouraged waste import. It is also reasonable to make up for the shortage of resources. In the process of China's industrialization, which was driven by the reform and its opening-up policy, raw materials needed for production, such as crude oil and wood, could be a much higher cost than the use of imported waste. The imported waste could ensure the availability of cheaper raw materials. To be fair, imported waste is not totally useless. Some foreign imported waste, such as waste plastics and waste paper, can be used for the production of recycled products. Some components of electronic waste can also be recycled. Through the disposal and utilization of waste, the insufficient supply of raw materials can be alleviated, and energy savings and emission reduction can also be facilitated in some way. Especially in the early stage of reform and opening up, under the background of the shortage of domestic resources and raw materials, waste import truly played a positive role.

\subsubsection{Restriction on the Import of Waste to Practice the Idea of Green Development}

For many developing countries, waste import can alleviate the shortage of domestic resources to some extent. However, for a long time, problems such as land and river pollution caused by imported waste could not be ignored. The import of foreign waste is a compromise that is made by many developing countries as a way to develop their economies.

There is a process to understand the harm caused by imported waste in China. In the beginning, waste import was permitted; then, the supervision of waste import was strengthened, and today, waste import is restricted or even banned. With the development of the economy, waste import has gradually become an increasingly intolerable problem. First, with the development of the economy, the insufficient raw material supply has been alleviated, and sometimes the raw material supply is even superfluous. There is not much demand for waste import. Second, in the process of imported waste recycling, secondary pollution easily occurs due to the backwardness of technology and the lack of supervision. Third, some unauthorized imported waste is poured, buried and accumulated without any treatment in China, which causes serious damage to the environment. Fourth, with the improvement of public awareness of environmental protection and the economic development concept from the pursuit of GDP to green sustainable development, waste import is no 
longer supported.

\subsection{Sampling Test}

According to the Huzhou City News, on April 9, 2018, Huzhou Customs of Zhejiang seized an amount of foreign wastes with excessive inclusions. This shipment of foreign waste, weighing 469 tons and with 40 containers in total, was sent from the United States to the customs port and then transferred to Huzhou's Anji Port Container Terminal. Huzhou Customs found that the waste paper not only smelled pungent but also contained a large number of used clothes, metal, waste beverage bottles and other inclusions. After identification, the content of inclusions reached 5.28\%, which seriously exceeded the standard of environmental protection for imported solid waste used as raw materials in China. The inclusions should not be more than $0.5 \%$ (see Figure 6). April was during the rainy spring season, and the temperature was rising rapidly, which was the right time for the propagation of bacteria. In addition, the waste paper and other inclusions had a pungent smell, so they surely would pollute the local environment for as long as it stayed at the wharf [11].
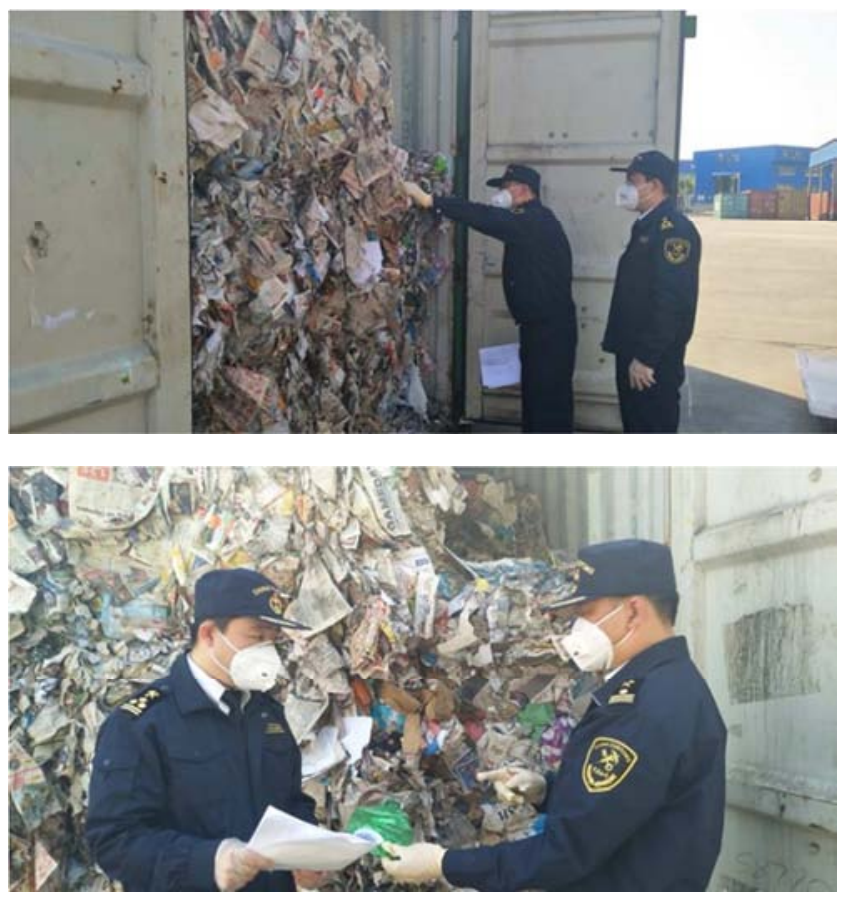

Figure 6. Foreign Waste Sampling Test by Huzhou Customs.

\subsection{Relevant Laws and Regulations}

Different countries have different legislative purposes and legal effects vary, which also brings difficulties to solving the problem of foreign waste in China [12]. Given this situation, China must have its own laws and regulations to deal with the entry of foreign waste. For the prevention and control of solid waste pollution, it is necessary to restrict or even ban the entry of foreign waste, crack down on smuggling and reduce the type and quantity of solid waste import. All these measures still need to be followed up by the advancement of relevant laws and regulations.
Laws, regulations and related systems must be improved. In July 2017, the General Office of the State Council of China issued a notice requiring the reform of the import management system for solid wastes, which required that the Measures for the Administration of Solid Waste Import should be amended to limit and reduce the number of ports of solid waste import. Furthermore, the import licensing system for solid waste should be improved, and the system of a trading agent for waste import should be abolished. In addition, the number of solid waste identification organizations should be increased to solve the outstanding problems of difficult identification. The State Council will timely request the National People's Congress to amend the Law of Environmental Prevention and Control for Solid Waste Pollution of the People's Republic of China, together with other laws and regulations, to increase the intensity of punishment for the smuggling of foreign waste and the illegal import of foreign waste [13].

At the same time, much work should be done to prepare a good policy interpretation for laws and regulations and provide good guidance for public opinion to ensure a smooth transition of national policies. The time for implementation of policies and management requirements in accordance with the rules and regulations should be made public. Much work is to be done for the comprehensive use of existing policies and measures to promote the transition of the industry, optimize the industrial structure, and re-employ workers such as waste collectors in the industry of foreign waste. To achieve sustainability within waste management systems, the significant role of waste collectors should be recognized [14]. By the end of 2020, hopefully, China will achieve the goal of zero import of solid wastes.

\subsection{Strengthening of Law Enforcement}

In addition to the following-up of laws and regulations, law enforcement needs to be strengthened as well.

The relevant departments of the State Council should continue to crack down on foreign waste smuggling. By making it a top priority of customs' work to crack down on foreign waste smuggling, China customs should strictly investigate and penalize the smuggling of hazardous waste, medical waste, electronic waste and household waste. Customs should further carry out all kinds of special anti-smuggling operations; increase efforts to crack down on smuggling at sea and places with no customs offices along the border; block foreign waste smuggling channels; and severely crack down on smuggling activities such as concealing, false declaration of cargo and so on. Foreign waste that is found in special anti-smuggling operations should be returned or destroyed in accordance with the law. The General Administration of Customs, the Ministry of Public Security and the China Maritime Police Bureau should be jointly responsible for the long-term implementation to strengthen supervision and severely crack down on smuggling of foreign waste. The long-term special action will focus on the smuggling of foreign waste, illegal import and use of waste plastics, waste paper, household waste, electronic waste, waste clothing and other solid waste. 
The relevant departments of the State Council should strengthen the whole process of supervision as well. By strictly examining the application for the import of solid waste, reducing the approval of the import license of solid waste, and controlling the total amount of licensed imports, the Ministry of Ecology and Environment of China should be responsible for the long-term implementation of strengthening the supervision and administration of key control points, such as the inspection of imported solid waste before shipment, the examination of results, the issuance of certificates, the strengthening of entry inspection and quarantine, and the strict enforcement of inspection standards. The General Administration of Quality Supervision, Inspection and Quarantine of China should be responsible for further increasing the inspection of imported solid waste in the long term. The General Administration of Customs of China should be responsible for the long-term implementation of strengthening on-site inspection of regulated enterprises with key risks and should severely investigate and penalize the resale of foreign waste, illegal processing and illegal utilization of imported waste.

\section{Results and Discussion}

\subsection{Promotion of Green Sustainable Development}

\subsubsection{Public Awareness of Environmental Protection}

The level of people's knowledge and perceptions about the use of urban green space may influence demand and decision-making behavior [15]. With the rapid development of the economy and urbanization, China is no longer satisfied with simply material prosperity. Therefore, the pursuit of a better ecological environment has reached an unprecedented level, and public awareness of environmental protection has awakened. The improvement of the people's awareness of environmental protection is, in fact, a reflection of their understanding of the new values of harmonious development that occurs between man and the natural environment, which has reached a new height. It is an important symbol of human civilization in modern society. It reflects the integrity and comprehensiveness of the relationship between man and nature. The increasing awareness of environmental protection makes people pay more attention to the changes in the natural environment and their influence on people's life.

First, the public pay more attention to the information on environmental protection. The rapid development of network technology has increased people's access to environmental protection information, and people's understanding of the impact of the ecological environment on their own health and daily lives is deepening day by day. In addition, with the improvement of living standards, people pay more attention to environmental protection information and how to improve the quality of life.

Second, the public are more willing to participate in environmental action. On the basis of deepening the publicity of protection of the ecological environment in all aspects of society, environmental protection organizations have carried out a large number of environmental protection activities in various forms and on different scales. People are more and more enthusiastic about participating in environmental protection activities, from the daily household waste sorting, the waste disposal of dry batteries, and mercury products to participation in tree planting and garbage-picking-up activity. The scale of various environmental protection activities is, indeed, expanding.

Last but not least, the public express more concern for the protection of the surrounding environment. As the public's concept of the protection of the ecological environment is enhanced with the increase of health knowledge, expectations for better quality of life are raised, and high attention is paid to things that may affect physical health, environmental damage, and living comfort. There is a stronger desire to protect their own rights and interests.

\subsubsection{Economic Transition with Green Sustainable Development to Be Realized}

The rise of China since its economic reform and opening up can be seen as a miracle in the history of human development. However, with the emergence of a new normal of economic development and the superposition of the problems in economic growth, a new concept of development is needed to lead China's economic and social development. China puts forward the five major development concepts of innovation, coordination, green, openness and sharing, with the characteristic of green sustainable development. The sustainability idea is put forward to comply with the requirements of the current era.

Each of the five major development concepts has its own specific connotation that aims at different problems and different goals, but as a whole, they integrate with and promote each other organically. Among them, innovation is the first driving force for economic and social development, and it is also the driving force for the development of the whole country. Therefore, it is at the top of the five major development concepts. Coordination, green, and opening up are the three important fulcrums of economic and social development. Sharing is the goal and destination of economic and social development and is the foothold of the five development concepts. Therefore, the five major development concepts have internal logic and structure, and their arrangements are not random [16].

Since its economic reform and opening up, China has created a miracle of rapid economic growth, but it is an extensive mode of growth that supports this miracle. While consuming huge amounts of resources, it has caused problems of tighter resource constraints, serious environmental pollution, and degradation of the ecosystem. In fact, it is a problem of environmental ethics. Environmental ethics, which are also called ecological ethics or environmental philosophy, is the study of the moral relationship between man and nature from the value and right of existence of nature. It aims to protect the ecological environment of the earth and uses certain environmental ethical principles and moral norms to regulate human environmental behavior. It emphasizes the 
concept of equality between man and nature, which is manifested as the equality of existence and the equality of interests. Although environmental pollution is expressed as an economic problem, it is essentially a problem of fairness [17]. The relationship between humans and nature has caused concern for the whole society. With the awakening of environmental awareness and the improvement of living standards, people are increasingly demanding fresh air, clean drinking water, safe food and beautiful environment. The deterioration of the ecological environment and its impact on people's health has become a prominent livelihood problem. Progressive scholars and ecological economists share similar concerns for the environment. Both locate the origins of the current environmental crisis firmly within the economy and seek sustainable alternatives to current modes of production and consumption [18]. In a comprehensive view of the international community, the green cycle of low carbon development is the basic direction of scientific and technological revolution and industrial reform, and it is also the most promising area of development. China's development potential in this area is considerable, and many new economic growth points can be formed. Therefore, people in China should adhere to the basic national policy of conserving resources and protecting environment; adhere to sustainable development; firmly follow the road of civilized development with productive development, a rich life, and good ecology; and speed up the construction of a resource-saving and environment-friendly society. There are advantages to understanding ethics from the point of view of responsibility rather than obligation [19]. It is time for China to form a new pattern of harmonious development between man and nature to promote the construction of beautiful country and to make new contributions to global ecological security. Green development is a sustainable development that follows the laws of nature, and it is also a necessity for China to build a prosperous society all-around.

\subsection{The Internal Relationship between Waste Import and Domestic Environmental Justice}

\subsubsection{Environmental Justice Issues Occurred between the Eastern Part of China and Western Part of China}

The western part of China is a vast region that has great influence on the ecological environment and economic development of other regions in China because of its special natural geographical and climatic conditions. The principles of environmental justice are grounded in ideals of social justice. They broadly call for economic alternatives that contribute to the development of environmentally safe livelihoods; policies based on mutual respect and justice for all peoples and free from any form of discrimination [20]. According to the current situation, the transfer of pollution from the eastern part to the western part of China is an important form of pollution transfer in China, and its constraints on economic and social development for the western part have been highlighted. If China does not pay attention to this problem and does not take active and effective measures, it will not only hinder the development of the western part of China itself but also directly affect the overall development of China.

Because the environmental pollution in the eastern part of China has reached a limit, and the economic development in the eastern part is obviously better than that of the western part, the pollution brought about by the economic development in the eastern part for several decades has made the eastern part of China no longer able to withstand the pollution of foreign waste. The development of resource-consuming industries also needs to transfer highly polluting industries to the western part. Therefore, imported waste or even imported household waste needs to be transferred to the western part of China to achieve lower cost. In that way, foreign waste may result in a secondary pollution for that region, and currently the direct import of foreign waste to the western part of China has become increasingly common, too. Most of the transferred foreign waste is difficult to dispose of and is highly prone to polluting soil and water.

Due to the backward economy and commerce in the western part of China, the local governments often give some preferential policies to attract industrial enterprises from the eastern part of the country to set up factories in the western region that will stimulate its economic development. As a result, the eastern part of the country, while purchasing resources cheaply from the western part, has also transferred resource destruction and environmental pollution to the western region. This transfer of pollution from the eastern part of China to the western part of China occurs by means of investment, so it can be said to be a problem of domestic environmental justice between the eastern and western parts of China.

\subsubsection{Environmental Injustice Occurred Partially between the Rich and Poor in China}

Enterprises from the eastern part of China have moved pollution industries that have raised production costs because of local strict environmental standards to the western part in the form of factories, which, in a sense, leads to waste import to the western region. This is a typical form of pollution transfer that is reflected in China, along with the unbalanced laws of economic development and the transfer of pollution in the global scope. In fact, it is the justice problem of environmental resources between rich and poor areas in China. Similarly, the transfer of industrial enterprises from urban to rural areas is also widespread. The transfer of pollution from urban to rural areas destroys the potential for long-term development of rural areas, exacerbates the gap between urban and rural areas and social contradictions, and violates the environmental equity between regions and generations [21]. Taking the city of Fuzhou as an example, industrial enterprises near its urban area first moved to the suburbs, and now all have moved to the countryside of its counties, leaving the city with clean water and blue sky; however, the countryside has counties with some form of pollution. The transfer of industrial enterprises from cities to villages will inevitably make the disposal and utilization of imported waste as raw materials more concentrated in rural areas. Thus, to 
some extent, the import of foreign waste exacerbates the environmental justice problems of the rich in cities and the poor in the countryside areas of China.

\subsection{The Internal Relationship between Waste Import and International Environmental Justice}

\subsubsection{Environmental Injustice Occurred among Different Races and Ethnic Groups}

If the success is simply to move the emitted pollutant to another, poorer, less-activist-involved community, state, or nation, the Environmental Justice activist will view the activity as a failure [22]. Under the background of economic globalization, many developing countries have joined the WTO, and pollution-intensive industries in the world are transferring to developing countries, including China, through investment and trade. When these industries are transferred to larger developing countries, such as China, high-pollution and high-energy-consumption products and foreign waste are also transferred. On the one hand, developing countries continue to export resources to some developed countries, while on the other hand, they continue to import foreign waste from the developed countries to supplement the growing consumption of domestic resources. However, the import of waste, in the meantime, causes environmental degradation and makes it an unsustainable vicious circle of economic growth. This is actually an environmental problem between different races and ethnic groups in the world. In the long run, international environmental justice issues will be highlighted and ultimately affect the people of the entire planet, because many environmental problems (e.g., climate change, acid rain, water pollution) are global, or at least transnational in their range of occurrence [23].

\subsubsection{Increased Tensions between Developed and Developing Countries}

In a broad sense, the transfer of pollution includes natural transfer and human transfer. Natural transfer mainly refers to the migration and diffusion of pollution by natural forces, such as wind and water. While human transfer is usually referred to as a behavior when a country, a region, an industry, or an enterprise, through trade, investment, etc. transfers technology and equipment that may cause harm to the environment and human health, as well as the production of products, consumption, or disposal of waste, to other countries or regions. The import and export of waste is "the conscious and intentional behavior of human beings", and the result is to sacrifice and damage others' environmental rights and interests in exchange for their own environmental rights and interests and economic benefit. The aim is to transfer the responsibility and cost of pollution control to other countries, places and other people. The essence of this move is to transfer the burden, loss and harm caused by environmental pollution to other weak parties so that they must bear the burdens, which has the effect of harming the community's overall interests and future development.

Internationally, the leading cause of global environmental degradation is the profligate consumption of the planet's resources by its wealthiest inhabitants [24]. Some developed countries, such as the United States, are large resource-consuming countries, as well as big waste emitters. Some developed countries or regions often purchase natural resources cheaply from developing countries but transfer resource destruction and environmental pollution to protect their own ecological environment. In China, in some way, the rapid development of the past 4 decades in the eastern part of China has been based on the excessive exploitation of the natural resources in the western part and the man-made destruction of the ecological environment of the western part. Therefore, it is also a special mode of pollution transfer.

Waste import and illegal waste smuggling have become a global pollution problem. In economic globalization of today, the transboundary movement of waste from rich countries to poor countries is no longer a secret. As early as the 1990s, distributive justice concerns have been raised. For example, there are reports that a Taiwan plastics company, which was unable to find a location in Taiwan to dispose of its mercury wastes, shipped the hazardous waste to Cambodia, where it ended up in an open pit, which resulted in the death of a local worker and threatened water supplies [25]. The mainland of China has become one of the main waste landfill sites of some developed countries, and some of its areas have become famous waste distribution centers of import waste. In May 2015, the United Nations Environmental Protection Agency (UNEP) published a report regarding garbage crime, garbage risk and the gaps and challenges in the waste sector. According to the report, it was found that 41 million tons of e-waste are generated globally each year, which is illegally traded or dumped. The proportion of e-waste sold (worth about US\$19 billion) is as high as $90 \%$, with computers and smartphones accounting for a larger proportion. In addition, the total amount of global electronic waste is in a growing trend. Countries in Asia and Africa, such as Ghana, Nigeria, China, Pakistan, India and Vietnam, are gradually becoming recycling bins for illegal electronic waste [26]. Environmental justice advocates have long called for the democratization of trade policy and have demanded that trade negotiations be open to a wide variety of participants and points of view. However, the technical nature of trade agreements and their grounding in economic theory can inhibit meaningful public participation [27]. Foreign waste causes serious environmental pollution and increases the cost of social management in these countries. To some extent, the gain outweighs the loss. In the long run, tensions between some developed and developing countries will inevitably arise because of conflicts in foreign waste import.

\subsection{Green Development Based on Environmental Justice and International Justice}

The backwardness of development concept and values can have a negative restriction and hindrance on the macro level of China's international trade and economic transition. To realize the expansion of international trade and the economic transition with high efficiency, the concept of green development must be incorporated into specific activities. 
The concept of green development is based on environmental justice and international justice. The pattern of China's economic growth in the past few decades is that the eastern part of China has made full use of the resources of the western part, and, at the same time, the eastern part has transferred pollution to the western part. This is the problem of environmental justice, in which the environmental benefit of sharing the distribution of environmental burden is unfair. From the international perspective, there are similar problems in the economic activities between China and some developed countries. On the one hand, China has been exporting resources to some developed countries, which has resulted in domestic pollution. On the other hand, some developed countries export foreign waste into China, which causes China's environmental problems to become even more serious. This is a problem of international justice, or more accurately, of international environmental justice.

It is good to see that the Chinese government and its people, in recent years, have generally recognized the importance of achieving green sustainable economic development. Furthermore, in the pattern of green sustainable development, China has obtained several development results. Some areas of China have begun to adapt themselves to local conditions to develop green industries and close industrial enterprises with pollution that exceeds the standard. The economic transition does not make China's GDP fall, but rather maintains a steady pace of economic growth, which is a green and high quality
GDP. Some underdeveloped areas in China have developed the green tourism industry according to local conditions, which attracts a large number of tourists and brings huge economic benefits. The number of days with haze weather in winter in northern China was significantly reduced because of green development. Therefore, the five major development concepts put forward by China are innovation, coordination, green, openness and sharing, which are characterized by green sustainable development and the concept of a Community of Shared Future for Mankind that is characterized by the common destiny of human beings. This concept is one of sharing the fruits of green and sustainable economic development to achieve international environmental justice so that the fruits of China's economic development post-reform and opening up can benefit people globally, and under the background of sluggish development of the global economy, it would allow the world to fully share the fruits of China's economic development, rather than being plundered on resources. It can be said that the Belt and Road initiative put forward by China is an embodiment of realizing the common development of the world and international justice of mankind based on the concept of a Community of Shared Future for Mankind. Thus, the world is surrounded by a universal concept of international justice that is green, sustainable, and commonly beneficial to share the fruits of economic development.

\begin{tabular}{|c|c|c|c|c|c|}
\hline \multirow{2}{*}{ No. } & \multirow{2}{*}{\multicolumn{2}{|c|}{ Type }} & \multicolumn{2}{|c|}{ Disposal mothod } & \multirow{2}{*}{ Remarks } \\
\hline & & & Bag & Cart, can, string etc. & \\
\hline 1) & \multicolumn{2}{|c|}{ Garbago } & $\begin{array}{l}\text { A2 } \\
\text { A3 }\end{array}$ & $\begin{array}{l}\text { Transport using } \\
\text { specifled garbage } \\
\text { carts. }\end{array}$ & $\begin{array}{l}\text { Do not include other types of } \\
\text { waste than garbage. } \\
\text { Drain thoroughly. } \\
\text { A2: to dispose of garbage } \\
\text { contained in biodegradable plastic } \\
\text { containers (A2 bags may not be } \\
\text { carried in methane fermentation } \\
\text { facility.) } \\
\text { A3: When only garbage is } \\
\text { disposed of }\end{array}$ \\
\hline 2) & \multicolumn{2}{|c|}{ Throwaway chopsticks } & B & & \\
\hline 3) & \multicolumn{2}{|c|}{ Glass bottles } & c & & Bottles should contain no residue. \\
\hline 4) & \multirow{3}{*}{ ซ్ } & Numinum cans & D & & Bottles should contain no residue. \\
\hline 5) & & Steel cans & $\mathbf{E}$ & & Bottles should contain no residue. \\
\hline 6) & & Professional-use cans & & & Bottles should contain no residue. \\
\hline 7) & \multicolumn{2}{|c|}{ Used cooking oil } & & $\begin{array}{l}\text { Wasto kitchon oil } \\
\text { should be placed in } \\
\text { profossional-uso cans } \\
\text { before disposal. }\end{array}$ & Can lids must be closed. \\
\hline 8) & \multicolumn{2}{|c|}{ PET bottles } & $\mathbf{F}$ & & Bottles should contain no residue. \\
\hline ө) & \multicolumn{2}{|c|}{ Plastic } & $\mathbf{G}$ & & \\
\hline 10) & \multicolumn{2}{|c|}{ Foamed polystyrene } & $\mathbf{H}$ & & \\
\hline 11) & \multirow{5}{*}{ 右 } & $\begin{array}{l}\text { Paper cups and } \\
\text { containers }\end{array}$ & J & & Flatten before placing into bag. \\
\hline 12) & & Cardboard boxes & \multirow{4}{*}{$\mathbf{K}$} & Tio with string. & The firmly. \\
\hline 13) & & Newspapers, leaflets & & Tie with string. & The firmly. \\
\hline 14) & & Magazines, brochures & & Tle with string. & The firmly. \\
\hline 15) & & $\begin{array}{l}\text { Omce equipment } \\
\text { paper }\end{array}$ & & Tle with string. & The firmly. \\
\hline 16) & \multicolumn{2}{|c|}{$\begin{array}{l}\text { Burnable waste (other than 1). } \\
\text { 2), 11), 12), 13), 14), and 15)) }\end{array}$} & $\mathbf{L}$ & & \\
\hline 17) & \multicolumn{2}{|c|}{$\begin{array}{l}\text { Unburnable waste (other than } \\
\text { 3) through 10)) }\end{array}$} & M & & \\
\hline
\end{tabular}

Figure 7. Waste Classification and Disposal Method. 
Therefore, China is striving to achieve the goal of zero imports of foreign wastes by the end of 2020 so that the green quality of its economic development will increase. China is also working to improve its waste recycling capacity, reduce carbon emissions, and provide people the benefit of a green, low-carbon lifestyle. In this regard, Japan has set up a good image for environmental protection to the world, and China is following suit. Source separation is considered to be an effective way to reduce waste and enhance recycling in many developed countries [28]. The classified collection of garbage is the basis and guarantee of effective garbage management and recycling in Japan. The Japanese government sends out "waste classification and disposal methods" graphic forms and publicity materials to every citizen (See Figure 7) [29].

On the one hand, to solve the difficulties in the treatment of imported waste, it is necessary to let the people in the "waste import industry chain" see the harm of foreign waste import and recognize the conflicts between immediate interests and long-term interests. On the other hand, it is essential to set up the concept of green development among the people in the "waste import industry chain" so that they can see the long-term harm and development constraints that are caused by its pollution to rivers, land, environment and ecology. Through a comparison of short-term value and long-term value, local value and overall value, the concept of green development is truly integrated into the consciousness and consensus of society.

In addition, the concept of green development based on the restriction on waste import can effectively promote the expansion of international trade so that people and society understand the necessity and importance of international trade expansion. Setting up the concept of green development based on the premise of restriction of waste import can effectively promote economic transition, thereby producing far-reaching effects for the public and governments at different levels. Only by forming a more accurate understanding of international trade and recognizing the nature of various problems in economic transition can China effectively cut off the chain of the waste import industry. On that basis, the green sustainable development of the Chinese economy will be realized.

\section{Conclusions}

Social justice is "that branch of the virtue of justice that moves us to use our best efforts to bring about a more just ordering of society - one in which people's needs are more fully met" [30]. It is an effective means for China to improve environmental quality by restricting or even banning the entry of foreign waste to advance the reform of the solid waste import management system, and that is an important task for the implementation of the new development concept, especially in the promotion of green development. People in China are required to protect the ecological environment as they protect their own eyes and treat the ecological environment as they treat their own lives. Only if China resolutely abandons the mode of development that damages or even destroys the ecological environment, as well as the practice of sacrificing the ecological environment for economic growth, can China's economic development be sustained. Speeding up the reform of the import management system of solid waste and keeping the foreign waste out of China will promote all local governments of China to change their concepts of development so that they adhere to the path of ecological priority and green development.

The treatment of foreign waste import is an important path for developing countries to realize the expansion of international trade and economic transition. Only by effectively carrying out the treatment of foreign waste import can China achieve the goal of economic prosperity, social development and an increasingly beautiful environment. Moreover, with scientific management of waste import, China can realize national and regional economic transition and promote green development.

\section{References}

[1] Sun, J; L, G. Environmental Policy of Renewable Resources Industry. Environmental Protection. 2017, 20, 002.

[2] Suzanne B. Goldbergd. Morals-Based Justification for Lawmaking: before and after Lawrence V. Twxas. 88 Minn. L. Rev. 1233.

[3] What does the ban on the entry of foreign waste signify? Available online: http://www.cenews.com.cn/gd/201704/t20170428_830850.html (accessed on 20 June 2018). (In Chinese).

[4] Jane B. Baron. Against Market Rationality: Moral Critiques of Economic Analysis in Legal Theory. 17 Cardozo L. Rev. 431.

[5] Song, Y; Gao, Z. On the legal Regulation of Foreign Waste. Journal of Yunnan University (Law Edition) 2014 , 27 (6) : 23-27.

[6] Tom E. R. B. Westa. Environmental Justice and International Climate Change Legislation: a Cosmopolitan Perspective. 25 Geo. Int'l Envtl. L. Rev. 129.

[7] Unswervingly Follow the Road of Green Development. Available online: http://epaper.tianjinwe.com/tjrb/html/2018-07/24/content_4640 2_297388.htm (accessed on 27 July 2018). (In Chinese).

[8] Guo, S; Ding, G; Zhao, Q; Jiang, M. Bonus Point System for Refuse Classification and Sustainable Development: A Study in China. Sustainability 2017, 9, 1776.

[9] Luis F. Marmolejo; Luis F. Diaz; Patricia Torres; Mariela García; Mary H. Burbano; Carolina Blanco; Katherine Erazo; Jairo F. Pereira. Influence of Handling Practices on Material Recovery from Residential Solid Waste. Sustainability 2010, 2, 2070-2083.

[10] La Vergne Lehmann. The Garbage Project Revisited: From a 20th Century Archaeology of Food Waste to a Contemporary Study of Food Packaging Waste. Sustainability 2015, 7, 6994-7010.

[11] Huzhou Customs Seized a Great Number of Inclusions seriously Exceeding the Standard in Waste Import. Available online: http://zj.qq.com/a/20180411/012296.htm (accessed on 1 June 2018). (In Chinese) 
[12] Zhang, J. Study on the Strategy of Coping with Foreign garbage in China under the background of Industry Moving Westward. Probe 2014 (6) : 109-113.

[13] Circular of the General Office of the State Council on the Issuance and Implementation of the Reform of the Administration System for the Import of Solid Waste. Available online:

http://www.gov.cn/gongbao/content/2017/content_5217742.htm (accessed on 5 July 2018). (In Chinese).

[14] Wael Fahmi; Keith Sutton. Cairo's Contested Garbage: Sustainable Solid Waste Management and the Zabaleen's Right to the City. Sustainability 2010, 2, 1765-1783.

[15] Yat Yen; Zhanqi Wang; Yumin Shi; Bunly Soeung. The Crowding-Out Effects of Garbage Fees and Voluntary Source Separation Programs on Waste Reduction: Evidence from China. Sustainability 2016, 8, 523.

[16] Chen, J. A Multi-dimensional Survey of the five Major Development Concepts. Ideological \& Theoretical Education 2016 (1) : 4-8.

[17] $\mathrm{Xu}, \mathrm{Y}$. Looking at the problem of foreign waste in China from the perspective of environmental inequity. Forward Position 2004 (7) : 170-172.

[18] Kristen A. Sheeran. Ecological Economics: a Progressive Paradigm? 17 Berkeley La Raza L. J. 21.

[19] Graham Mayeda. Where Should Johannesburg Take us? Ethical and Legal Approaches to Sustainable Development in the Context of International Environmental Law. 15 Colo. J. Int'l Envtl. L. \& Pol'y 29.

[20] Principles of Environmental Justice, supra note 12, at pmbl., nos. $2,12$.
[21] $\mathrm{Li}, \mathrm{X} ; \mathrm{He}, \mathrm{A}$. Interests paradox and its countermeasure research of pollution transfer from urban to rural areas. Chinese Journal of Population Resources and Environment 2016, 26 (8) : 56-62.

[22] Raina Wagner. Adapting Environmental Justice: in the Age of Climate Change, Environmental Justice Demands a Combined Adaptation-Mitigation Response. 2 Ariz. J. Envtl. L. \& Pol'y 153.

[23] David Wilkinson. Environment and Law. Routledge Introductions to Environment Series 2002.

[24] See U. N. Millennium Ecosystem Assessment, supra note 7, at $1-24$.

[25] What to Do With All That Waste? Bus. Wk., Jan.18, 1999, at26.

[26] Fan, P. On Legal Regulations for Importing Oversea Wastes. Journal of Hebei University of Economics and Trade (Comprehensive Edition) 2016, 16 (3) : 42-47.

[27] Carmen G. Gonzalez. An Environmental Justice Critique of Comparative Advantage: Indigenous Peoples, Trade Policy, and the Mexican Neoliberal Economic Reforms. 32 U. Pa. J. Int'l L. 723.

[28] Han, H; Zhang, Z; Xia, S. The Crowding-Out Effects of Garbage Fees and Voluntary Source Separation Programs on Waste Reduction: Evidence from China. Sustainability 2016, 8, 678.

[29] Guo, F. Reflections on the Import of Foreign Garbage and Responses to the Recovery of Chinese Waste Resources. Journal of Financial and Economic Theory 2014 (6) : 45-51.

[30] Robert E. Rodes Jr., Social Justice and Liberation, 71 Notre Dame L. Rev. 619, 620 (1996). 